(c) American Dairy Science Association, 2006.

\title{
Altering Renneting pH Changes Microstructure, Cell Distribution, and Lysis of Lactococcus lactis AM2 in Cheese Made from Ultrafiltered Milk
}

\author{
J. A. Hannon, ${ }^{1}$ C. Lopez, M.-N. Madec, and S. Lortal \\ UMR 1253 Science et Technologie du Lait et de l'Oeuf, INRA-Agrocampus-65, 35042 Rennes Cedex, France
}

\begin{abstract}
The objective of this study was to investigate the lysis of a highly autolytic strain of Lactococcus lactis ssp. cremoris AM2 in a model cheese made from concentrated ultrafiltered milk. From the same initial ultrafiltered retentate inoculated with $L$. lactis AM2, 5 cheeses were made by the addition of rennet at different $\mathrm{pH}$ values $(6.6,6.2,5.8,5.4$, and 5.2). Lysis was monitored by measurement of the release of lactate dehydrogenase, an intracellular marker enzyme, and by immunodetection of intracellular proteins with species-specific antibodies. Confocal scanning laser microscopy (CSLM) was used to investigate the cheese microstructure by staining for protein and fat. Dual staining with a bacterial viability kit with CSLM was performed to reveal the integrity and localization of the bacterial cells. Levels of soluble calcium significantly increased when the $\mathrm{pH}$ at which the rennet was added decreased. In cheese renneted at $\mathrm{pH}$ 6.6, CSLM revealed an open porous structure containing a dense protein network with fat globules of different sizes distributed in the aqueous phase. In cheese renneted at $\mathrm{pH} 5.2$, the protein network was homogeneous, with a less dense protein network, and an even distribution of fat globules. On d 1, bacterial cells were organized into colonies in cheese renneted at $\mathrm{pH} 6.6$, whereas in cheeses renneted at $\mathrm{pH} 5.2$, bacteria were evenly dispersed as single cells throughout the protein network. Lysis was detected on $\mathrm{d} 1$ in cheeses renneted at high $\mathrm{pH}$ values and continued to increase throughout ripening, whereas induction of lysis was delayed in cheeses renneted at lower $\mathrm{pH}$ values until the end of ripening. This study demonstrates that alterations in the microstructure of the cheese and the distribution of cells play a role in lysis induction of L. lactis AM2.
\end{abstract}

Key words: lysis, lactic acid bacteria, $\mathrm{pH}$ of renneting, microstructure

Received August 2, 2005.

Accepted October 14, 2005.

${ }^{1}$ Corresponding author: john.hannon@rennes.inra.fr

\section{INTRODUCTION}

The use of UF technology in concentrating milk for cheese making has achieved much commercial success since its introduction in 1969 (Maubois et al., 1969). During the ultrafiltration of milk, NPN and soluble components such as lactose, salts, and some vitamins pass through the membrane, whereas milk fat, proteins, and colloidal salts are retained in the retentate (Maubois and Mocquot, 1971). The use of such UF retentate for cheese making can result in increases of up to $20 \%$ in yield from the inclusion of whey proteins, as well as increases in the nutritive value of the product, simplification of the cheese-making process, reduced rennet requirements, and consequently, economic savings. Ultrafiltration technology has been widely used in the manufacture of fresh soft and semihard cheeses, but the technology has not proved as beneficial in the manufacture of hard cheeses (Pedersen and Ottosen, 1992; Mistry and Maubois, 2004).

Despite these advantages, many reports have shown that proteolysis and flavor development of UF cheese made from 5-fold or fully concentrated milk is slowed compared with traditional cheese ripening (de Koning et al., 1981; Spangler et al., 1989). The presence of extra whey proteins, both denatured and undenatured, which are resistant to hydrolysis by chymosin (Creamer et al., 1987), lactic starter proteases, and plasmin (Visser, 1981), as well as an increase in the buffering capacity (thought to be a factor in inhibiting cell lysis; Goudédranche et al., 1981; Saboya et al., 2001; Mistry and Maubois, 2004) have all been proposed as reasons for this reduction in the rate of ripening. However, according to Mistry and Maubois (2004), many of these hypotheses are controversial. In a previous study, Hannon et al. (2006) demonstrated the differential lytic behavior between species of mesophilic lactococci and thermophilic lactobacilli. The authors have reported that cell lysis of Lactococcus lactis ssp. cremoris AM2 was retarded in UF cheese compared with previous reports in the literature on the behavior of this strain in traditional-type cheese.

The positive correlation between autolysis of starter strains and the development of enhanced proteolysis 
and improved organoleptic properties in traditional types of cheese have been well documented (ChapotChartier et al., 1994; Wilkinson et al., 1994; Deutsch et al., 2002; Hannon et al., 2003; Lortal and ChapotChartier, 2005). In UF cheeses, studies have shown that it is possible to influence proteolysis by using starter strains selected for this purpose (Qvist et al., 1987), by alterations in levels of addition of rennet (de Koning et al., 1981), by addition of proteolytic enzymes (Saboya et al., 2001) and attenuated starters (Goudédranche et al., 1986; Spangler et al., 1989; Klein and Lortal, 1999), or by increasing the available amount of plasmin by addition of a plasminogen activator (Bastian et al., 1991). These studies have shown that it is possible to accelerate the ripening of UF cheese, mainly by increasing the level of active enzymes in the cheese matrix early in the ripening. Hence, the induction of earlier lysis of starter bacteria should release intracellular enzymes into the cheese body and increase the rate of proteolysis in UF cheeses.

In studies dealing with the absence of early lysis of starter cultures in UF cheeses, rennet was added after acidification, i.e., $\mathrm{pH} \sim 5.2$ (Saboya et al., 2001, 2002; Hannon et al., 2006). It has been reported that texture of UF cheese was improved when the rennet was added after acidification rather than before acidification (as in more traditional-type cheese making), and that such texture is preferred by cheese graders (Goudédranche et al., 1980). The alteration of the $\mathrm{pH}$ at which rennet is added has a significant effect on the physicochemical parameters of the micellar casein and, hence, the resultant cheeses (Gastaldi et al., 1996), which in turn has implications for the microenvironment and growth conditions for starter strains. The effect of altering the renneting $\mathrm{pH}$ on lytic behavior of starter strains has not been explored previously.

The objective of this study was to investigate the effect on the onset and extent of starter strain lysis in UF cheese due to altering the $\mathrm{pH}$ at which rennet was added. The model strain selected is a highly autolytic strain (AM2) of Lactococcus lactis ssp. cremoris, the behavior of which has been well documented in the literature for traditional-type cheese.

\section{MATERIALS AND METHODS}

\section{Origin of Strains and Growth Conditions}

The strain used was Lactococcus lactis ssp. cremoris AM2 obtained from the Center National de Recherche Zootechnique (Institut National de la Recherche Agronomique, Jouy en Josas, France). It was stored at $-70^{\circ} \mathrm{C}$ in M17 broth [supplemented with $0.5 \%$ (wt/vol) lactose; Difco, Sparks, MD] supplemented with 15\% (vol/vol) glycerol before freezing. For cheese trials, cultures were revived from frozen stocks before use, propagated by 2 successive transfers in M17 broth supplemented with $0.5 \%$ (wt/vol) lactose, and stored at $4^{\circ} \mathrm{C}$ until use. The day before cheese making, $L$. lactis ssp. cremoris AM2 was inoculated into UHT milk (2\%) and grown overnight at $30^{\circ} \mathrm{C}$.

\section{Microfiltration and Ultrafiltration of Milk}

The process of microfiltration and UF used are described in Hannon et al. (2006). Briefly, raw milk (240 $\mathrm{kg}$ ) was skimmed using a cream separator (Westfalia, Chateau-Thierry, France), the skimmed portion was heated to $50^{\circ} \mathrm{C}$, and microfiltered using a Tetra Alcross Pilot M1X7 microfiltration unit (Tetra Pak Filtration System A/S, France) equipped with Sterilox GP membranes and pore size of $0.8 \mu \mathrm{m}$. The cream fraction was sterilized at $120^{\circ} \mathrm{C}$ for $20 \mathrm{~s}$ (Actijoule pilot, Société Actini, Evian, France), after which it was cooled to $4^{\circ} \mathrm{C}$ until use. Cream and microfiltered skim milk were recombined to give a final milk fat content of $28 \mathrm{~g} / \mathrm{kg}$. Ultrafiltration was performed using a UF pilot equipment (T.I.A., Bollene, France) equipped with Membralox membranes with a membrane pore size of $0.05 \mu \mathrm{m}$, surface area of $1.6 \mathrm{~m}^{2}$ (Pall Industrie, Saint-Germainen-Laye, France), and a molecular weight cut-off of $10,000 \mathrm{Da}$. The temperature during the UF process was maintained at 50 to $55^{\circ} \mathrm{C}$. Diafiltration of the retentate by addition of water $(1.12 \mathrm{vol} / \mathrm{vol})$ was performed after a 6 -fold concentration of the retentate was achieved. The final concentration factor of 6 was determined by the volume of permeate obtained. Following UF treatment, retentate was collected in vats and $0.75 \% \mathrm{NaCl}$ added, before cooling to $30^{\circ} \mathrm{C}$ for inoculation. Total bacterial counts in the UF retentate were $1.5 \times 10^{2} \mathrm{cfu} /$ $\mathrm{mL}$ retentate.

\section{UF Cheese Manufacture}

Five kilograms of the retentate (at $30^{\circ} \mathrm{C}$ ) containing $0.75 \% \mathrm{NaCl}$ was weighed into a sterile flask and inoculated with $2 \%$ of a fully grown overnight culture of $L$. lactis AM2 to achieve a $10^{7} \mathrm{cfu} / \mathrm{mL}$ of retentate. This was left for $0.5 \mathrm{~h}$ with occasional agitation before dividing into five 1-L portions. This ensured that the starting material was uniform for all cheeses. A sample was also taken to monitor the acidification profile (incubated at $30^{\circ} \mathrm{C}$ ) using a CINAC pH probe (Ysebaert, Frepillon, France). Five different $\mathrm{pH}$ values were chosen- $\mathrm{pH}$ 6.6, $6.2,5.8,5.4$, and 5.2-at which the rennet was added. Following the acidification profile, as each $\mathrm{pH}$ value was reached, a further $0.75 \% \mathrm{NaCl}$ was added before the addition of rennet (Maxiren 600-DSM, Lille, France) at a concentration of $25 \mathrm{~mL} / 100 \mathrm{~kg}$. The flasks 
were mixed thoroughly to ensure even dispersion, before aseptically pouring into 10 sterile screw-capped bottles each containing $100 \mathrm{~mL}$. All bottles were stored at $30^{\circ} \mathrm{C}$ until $2 \mathrm{~h}$ after $\mathrm{pH} 5.2 \mathrm{had}$ been reached before storing at $12^{\circ} \mathrm{C}$ for $28 \mathrm{~d}$.

\section{Composition of UF Cheeses}

The composition of the retentate was previously described in Hannon et al. (2005): 41.6\% DM, 16.2\% fat, $19.4 \%$ total protein, $3.66 \%$ noncasein nitrogen, $1.79 \%$ $\mathrm{NPN}, \mathrm{pH}=6.70$. Cheeses were sampled on $\mathrm{d} 1$ for compositional analysis. For each sample, $\mathrm{pH}, \mathrm{DM}$, salt, and lactose content were determined. The $\mathrm{pH}$ was measured with a standard CG837 pH meter with InLAB 427 electrodes (Mettler Toledo, Viroflay, France) by direct insertion into the cheeses. Dry matter was measured by drying at $102^{\circ} \mathrm{C}\left( \pm 2^{\circ} \mathrm{C}\right)$ for $7 \mathrm{~h}$, according to IDF (1982). Salt was determined using a Corning Chloruremetre 926 (Humeau Laboratoires, La Chapelle-sur-Erdre, France). The residual lactose in the cheese was measured using a Boehringer kit (Mannheim, Germany). Soluble calcium was measured in the cheese aqueous extract obtained directly after the addition of rennet on the day of cheese making. Cheese samples were ultracentrifuged at ambient temperature $(100,000 \times g$ for $1 \mathrm{~h}$ ) to obtain an aqueous phase and calcium concentrations determined using atomic absorption spectroscopy (AA300, Varian, Les Ulis, France) according to Le Graët and Gaucheron (1999).

\section{Starter Viability}

Cheese samples $(10 \mathrm{~g})$ were homogenized in $90 \mathrm{~g}$ of trisodium citrate $(2 \% \mathrm{wt} / \mathrm{vol})$ using a stomacher (Laboratoires Humeau) for $2 \mathrm{~min}$ at the middle setting rate. Decimal dilutions were prepared with a peptone-saline solution ( 1 and $0.5 \mathrm{~g} / \mathrm{L}$, respectively). Viability of $L$. lactis ssp. cremoris AM2 was determined by the pourplate technique on M17 agar plates (Terzaghi and Sandine, 1975), supplemented with 5\% (wt/vol) sterile lactose. Plates were incubated at $30^{\circ} \mathrm{C}$ for $48 \mathrm{~h}$. Duplicate cheese samples were taken and the averaged results were expressed in colony-forming units per gram of wet cheese. Starter viability counts were carried out on $d$ $1,7,14$, and 28 .

\section{Aqueous Cheese Extracts}

Each sample of cheese ( $5 \mathrm{~g}$ ) was diluted to $25 \mathrm{~mL}$ with distilled water in a filter stomacher bag (Laboratoires Humeau) and ground manually at room temperature for $15 \mathrm{~min}$ as described by Valence et al. (1998). The mixture was centrifuged $\left(10,000 \times g, 15 \mathrm{~min}, 4^{\circ} \mathrm{C}\right)$, and the supernatant filtered with a $0.45-\mu \mathrm{m}$ filter (Sartorius, Hanover, Germany). The filtered aqueous cheese extracts were analyzed immediately for total lactate dehydrogenase (LDH) activity and SDS-PAGE as described below. Two independent replications of cheese samples were carried out on d 1, 7, 14, and 28 .

\section{Total LDH Activity}

Total LDH activity was assayed in triplicate by the method of Cogan et al. (1981) using pyruvate as substrate in the presence and absence of the cofactor fructose-1,6 bisphosphate. Activity was expressed as units per milliliter of aqueous cheese extract, in which one unit was defined as the amount of enzyme that catalyzes the oxidation of one micromole of NADH per minute at ambient temperature. Each assay was carried out on d 1, 7, 14, and 28 in triplicate on independent replicates and average results presented.

\section{SDS-PAGE and Immunoblotting}

Proteins in the aqueous cheese extracts were analyzed by denaturing PAGE (SDS-PAGE), as described by Valence and Lortal (1995). Samples were mixed (vol/ vol) in Laemmli buffer and loaded on the gel (12\% separating gel) with migration induced at a constant voltage of $180 \mathrm{~V}$ for $1 \mathrm{~h}$ at room temperature. This was followed by Western blotting transfer $(1.25 \mathrm{~h}$ at $250 \mathrm{~mA}$, constant current) onto a nitrocellulose sheet $(0.45-\mu \mathrm{m}$ pore size, Millipore, St Quentin-en-Yveline, France; Towbin et al., 1979). A first antibody directed against the intracellular marker X-prolyl-dipeptidyl-aminopeptidase (Pep-X) from L. lactis was obtained from Eurogentic (Seraing, Belgium; Chapot-Chartier et al., 1994), stored at $-20^{\circ} \mathrm{C}$, and diluted $1 / 1000$ in PBS-Tween before use). Horseradish peroxidase-conjugated goat antirabbit IgG $(\mathrm{H}+\mathrm{L})$-HRP conjugate (BioRad, Hercules, CA) was used as the secondary antibody with 3,3 'diaminobenzidine tetrahydrochloride (Amresco, Solon, $\mathrm{OH}$ ) used as chromogenic substrate.

\section{Proteolysis}

Free amino acids (FAA) in filtered aqueous cheese extracts were quantified using the cadmium ninhydrin reagent (Baer et al., 1996) with methionine as standard. The aqueous extracts were incubated at room temperature for $1.5 \mathrm{~h}$ with absolute ethanol $80 \%$ ( $\mathrm{vol} / \mathrm{vol}$ ). After centrifugation $\left(5,000 \times \mathrm{g}, 15 \mathrm{~min}, 4^{\circ} \mathrm{C}\right), 50 \mu \mathrm{L}$ of supernatant was mixed with $550 \mu \mathrm{L}$ of distilled water, and $1.25 \mathrm{~mL}$ of the Cd-ninhydrin solution was added. Each assay was carried out on $\mathrm{d} 1$ and 28 in triplicate; results were expressed in micromoles per milliliter of aqueous extract. 


\section{CSLM}

Microstructure. Thin slices $(5 \times 5 \mathrm{~mm})$ approximately 3-mm thick were cut from the UF cheeses with a scalpel, immediately after removing the samples from the ripening room on $\mathrm{d} 1$ and 28 of ripening. The protein network was stained using acridine orange fluorescent dye (Aldrich Chemical Company, Inc., Milwaukee, WI). A lipid-soluble Nile Red fluorescent dye (Sigma-Aldrich, St. Louis, MO) was used to label fat. Each slice was placed between a microscope slide and coverslip. The samples were kept at $4^{\circ} \mathrm{C}$ for 30 min to allow diffusion of the fluorescent dyes. Microstructural analysis was made using CSLM. The confocal Leica TCS NT microscope (Leica Microsystems, Heidelberg, Germany) used an argon/krypton laser in dual-beam fluorescent mode, with excitation wavelengths of 568 and $488 \mathrm{~nm}$ for fat and protein, respectively. The two-dimensional images had a resolution of $1024 \times 1024$ pixels and the pixelscale values were converted into micrometers using a scaling factor. In the double-stained samples, the fat phase was red and the protein phase was gray. Aqueous phase and any microscopic air bubbles in the slices appear as black holes in the confocal micrographs.

LIVE/DEAD Bacteria Staining. The method involving LIVE/DEAD BacLight viability staining was used as previously described (Gardiner et al., 2000). The LIVE/DEAD BacLight stain (Molecular Probes Inc., Leiden, The Netherlands) was added to freshly cut sections $(5 \times 5 \times 3 \mathrm{~mm})$ of UF cheeses placed on a microscope slide at $\mathrm{d} 1$ and 28 of ripening. The kit is composed of 2 fluorescent nucleic acid stains: SYTO9 and propidium iodide. Briefly, SYTO9 penetrates both viable and nonviable bacteria, whereas propidium iodide penetrates bacteria with damaged plasma membranes only, quenching the green SYTO9 fluorescence. Thus, bacterial cells with compromised membranes fluoresce red and those with intact membranes fluoresce green. Twenty-five microliters of SYTO9 solution and $25 \mu \mathrm{L}$ of propidium iodide solution were spread onto the samples and a coverslip placed on top. Cheese slices were incubated with the stains for $30 \mathrm{~min}$ in darkness at $4^{\circ} \mathrm{C}$, and CSLM was performed as described above. Simultaneous pseudocolor dual-channel CSLM imaging with 488-nm excitation was used to display green fluorescence and red fluorescence, which represent live and dead cells, respectively.

\section{Statistical Analyses}

Total LDH and total FAA data were analyzed by ANOVA using a GLM procedure. A statistical model was constructed and fitted with terms to account for variations due to renneting $\mathrm{pH}$, ripening time, and the interaction of renneting $\mathrm{pH}$ and ripening time. The AN-
Table 1. Time at which rennet was added and bacterial populations for each renneting $\mathrm{pH}$ after inoculation of Lactococcus lactis AM2 on day of manufacture of UF cheeses

\begin{tabular}{lll}
\hline $\begin{array}{l}\text { Renneting } \\
\mathrm{pH}\end{array}$ & $\begin{array}{l}\text { Time of } \\
\text { renneting }\end{array}$ & $\begin{array}{l}\text { Population } \\
\text { (log cfu/g } \\
\text { of cheese) }\end{array}$ \\
\hline 6.6 & 1.0 & 7.69 \\
6.2 & 3.8 & 8.66 \\
5.8 & 4.5 & 8.93 \\
5.4 & 6.2 & 9.04 \\
5.2 & 9.0 & 9.08 \\
\hline
\end{tabular}

${ }^{1}$ Time at which rennet was added after initial inoculation.

OVA was carried out using SPSS v 8.0 (SPSS Inc., Chicago, IL). Differences among treatments that are described subsequently as being significant were determined at $P<0.05$.

\section{RESULTS}

\section{Acidification of UF Retentate}

To ensure that the initial retentate used for each cheese had the same starting composition and the same level of starter, the retentate was divided into five 1-L flasks $0.5 \mathrm{~h}$ after inoculation of L. lactis ssp. cremoris AM2. Time at which rennet was added and populations of viable cells in each flask after inoculation by starter bacteria, in relation to renneting $\mathrm{pH}$, are given Table 1. Each flask was thoroughly mixed after the addition of rennet before pouring into bottles. Viable populations of lactococcal starter on d 1 were between $7.4 \times 10^{8}$ and $9.1 \times 10^{9} \mathrm{cfu} / \mathrm{g}$ cheese for all cheeses (Figure 1). Populations of AM2 were slightly higher in cheeses to which rennet was added at $\mathrm{pH} 5.4$ and 5.2 compared with the other 3 cheeses. All cheeses showed a progressive reduction in viability from $\mathrm{d} 1$ to 28 , with the exception of cheese renneted at $\mathrm{pH} 5.2$, which showed a rapid reduction between $\mathrm{d} 14$ and 28 .

\section{Compositional Analysis}

The compositions of the cheeses on $\mathrm{d} 1$ are given in Table 2. Dry matter content was similar in all the cheeses and comparable to the retentate. Levels of soluble calcium detected in the aqueous phase of the cheeses on the day of manufacture increased greatly with reduction of the $\mathrm{pH}$ at which rennet was added (Figure 2). Around 5 times as much soluble calcium was detected in the aqueous phase of cheese renneted at pH $5.2 \mathrm{com}-$ pared with that renneted at $\mathrm{pH}$ 6.6.

\section{$L D H$}

The ANOVA of the LDH values detected revealed that significant differences $(P<0.05)$ existed due to the 


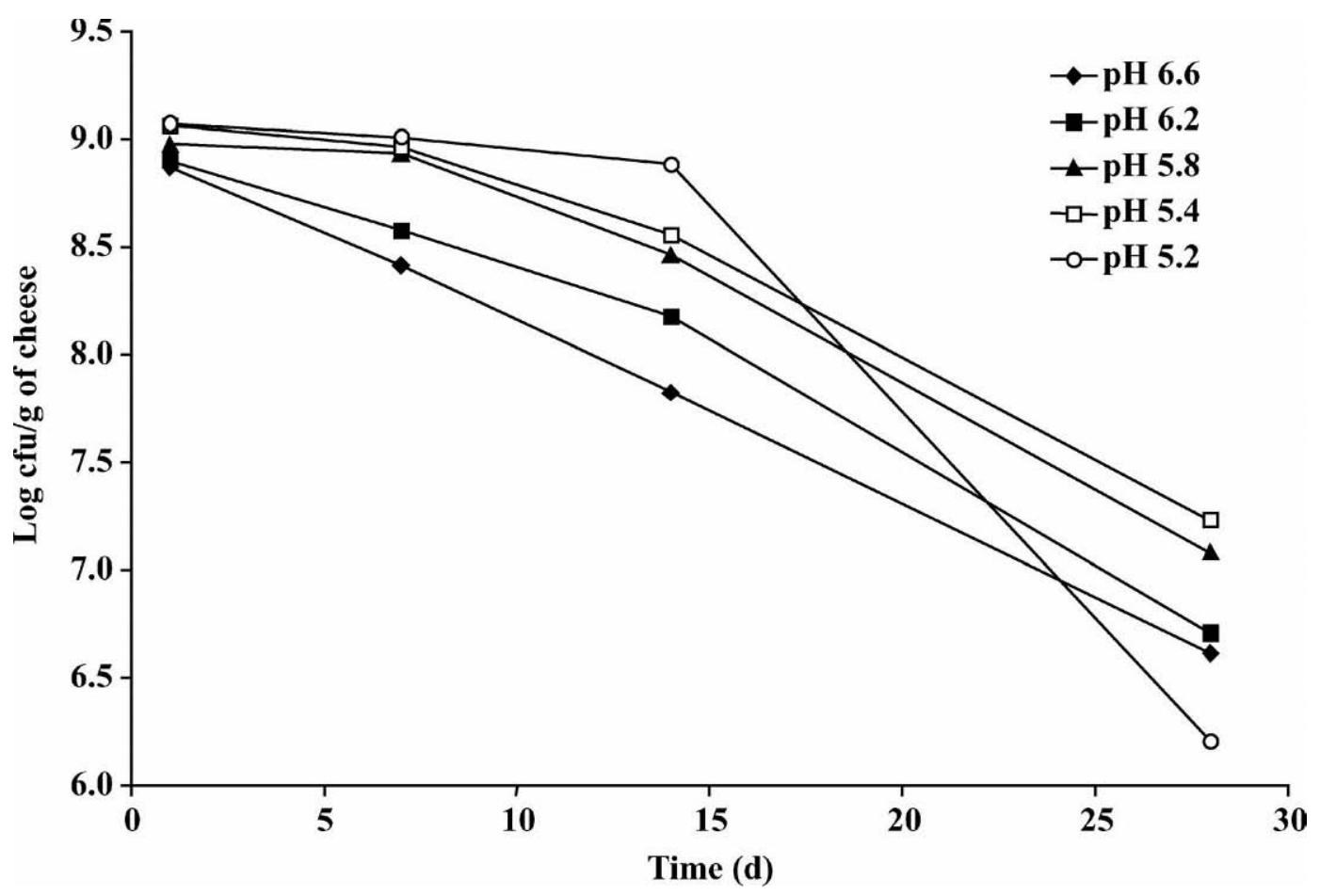

Figure 1. Enumeration of Lactococcus lactis ssp. cremoris AM2 throughout the 28-d ripening period of UF cheeses manufactured using different renneting $\mathrm{pH}$ values.

renneting $\mathrm{pH}(\mathrm{df}=4, \mathrm{~F}=3035.13, P \leq 0.000)$, ripening time ( $\mathrm{df}=3, \mathrm{~F}=17,160.57, P \leq 0.000)$, and the interaction of renneting $\mathrm{pH}$ and ripening time $(\mathrm{df}=12, \mathrm{~F}=$ $726.23, P \leq 0.000$ ). On $\mathrm{d} 1$, cheeses renneted at $\mathrm{pH} 6.6$ and 6.2 had 3.4 and 2.5 times more LDH detected, respectively, than cheese renneted at $\mathrm{pH} 5.2$ (Figure 3 ). By d 7, cheeses renneted at $\mathrm{pH} 6.6$ and 6.2 had 5.1 and 4.9 times more LDH detected, respectively, than cheese made with rennet addition at $\mathrm{pH}$ 5.2. Cheeses renneted at $\mathrm{pH} 5.4$ and 5.2 showed very little increases in levels of LDH up to d 14. However, similar levels of $\mathrm{LDH}$ were detected in all cheeses by the end of ripening, irrespective of the $\mathrm{pH}$ at which rennet was added. The patterns detected correlate well with the reduction in

Table 2. Compositional analysis (with standard deviations) of UF cheeses on $\mathrm{d} 1$ made with the addition of rennet at different $\mathrm{pH}$ values

\begin{tabular}{llllll}
\hline & \multicolumn{4}{c}{ Cheese at d 1 } \\
\cline { 2 - 5 } $\begin{array}{l}\text { Renneting } \\
\mathrm{pH}\end{array}$ & $\mathrm{pH}$ & $\begin{array}{c}\mathrm{DM} \\
\mathrm{g} / 100 \mathrm{~g} \\
\text { of cheese) }\end{array}$ & $\begin{array}{c}\text { Salt } \\
(\mathrm{g} / 100 \mathrm{~g} \\
\text { of cheese) }\end{array}$ & ${\mathrm{S} / \mathrm{M}^{1}}$ \\
\hline 6.6 & $5.18(0.01)$ & $37.6(0.3)$ & $1.56(0.2)$ & 2.50 \\
6.2 & $5.17(0.01)$ & $36.1(0.2)$ & $1.61(0.3)$ & 2.52 \\
5.8 & $5.11(0.02)$ & $36.2(0.2)$ & $1.55(0.2)$ & 2.43 \\
5.4 & $5.08(0.02)$ & $36.2(0.3)$ & $1.66(0.3)$ & 2.60 \\
5.2 & $5.07(0.03)$ & $36.3(0.2)$ & $1.60(0.3)$ & 2.51 \\
\hline
\end{tabular}

${ }^{1} \mathrm{~S} / \mathrm{M}=$ Salt in moisture. viability as shown in Figure 1. Release of intracellular $\mathrm{LDH}$ and, hence, induction of lysis was clearly shown to occur earlier in cheeses to which rennet had been added at higher $\mathrm{pH}$ values.

\section{Immunoblot Detection of Intracellular Marker Enzyme}

To confirm lysis and the release of intracellular enzymes, immunoblot detection of the intracellular enzyme Pep-X was performed on d 1, 7, and 28 (Figure 4). On d 1, bands were observed only for cheeses renneted at $\mathrm{pH} 6.6$ and 6.2. No Pep-X band was observed for the other cheeses, in agreement with the levels of LDH detected. By d 28, however, Pep-X bands were observed for all cheeses, indicating that lysis had occurred in all cheeses by this time.

\section{CSLM}

The structure of the protein network as well as the distribution of fat was investigated on 1 by CSLM only on cheeses renneted at $\mathrm{pH} 6.6$ and 5.2. When rennet was added at $\mathrm{pH} 6.6$ (Figure 5a), CSLM revealed a very open, porous network as indicated by the presence of large areas of black coloration, which correspond to aqueous phase or air pockets. A dense white protein 


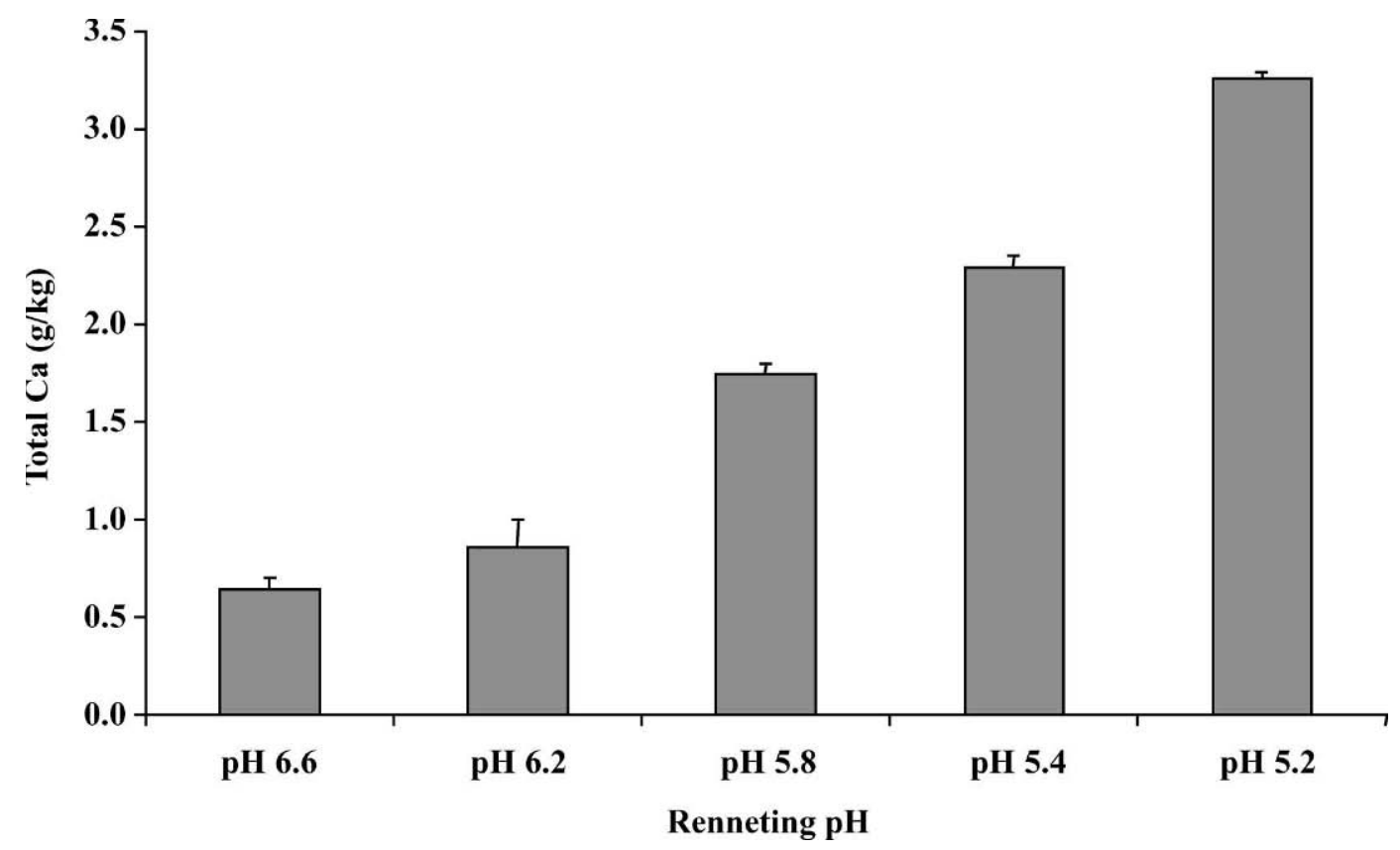

Figure 2. Levels of soluble calcium in the aqueous phase of UF cheeses detected after the addition of rennet at $5 \mathrm{pH}$ levels on the day of manufacture of UF cheese. Results are the means of replicate analyses.

network was observed with interspersed fat globules of diverse sizes. The coalescence of fat globules was observed as indicated by the presence of irregular- shaped red areas reflecting destruction of the fat globule membrane. Air pockets were formed during agitation with the more viscous retentate trapping air as the gel

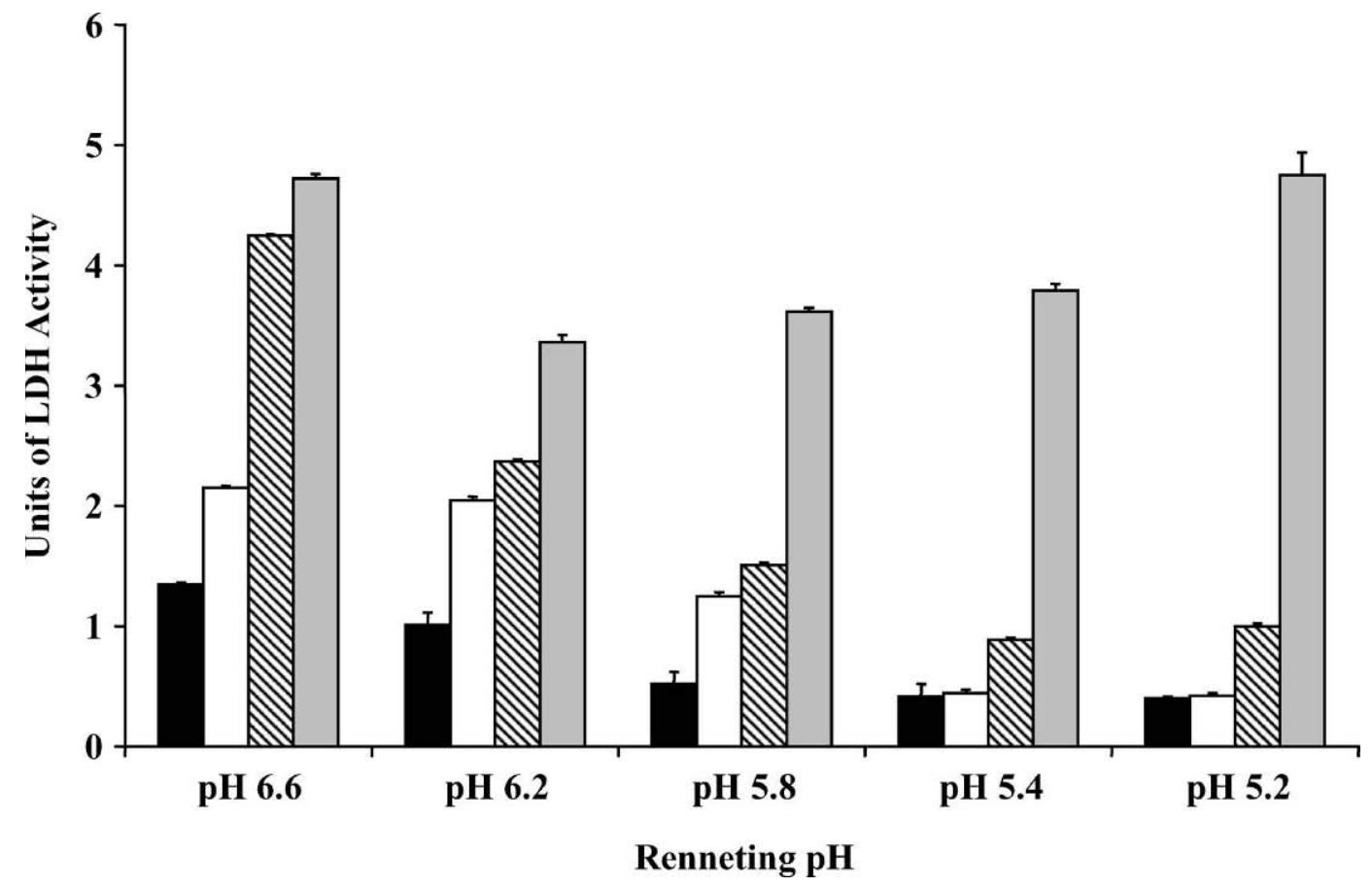

Figure 3. Total lactate dehydrogenase (LDH) activity detected in UF cheeses manufactured using different renneting pH values on d 1 (匹), 7 ( $\square$ ), 14 (diagonal hatch), and 28 (gray). Results are the means of 2 independent replications. 


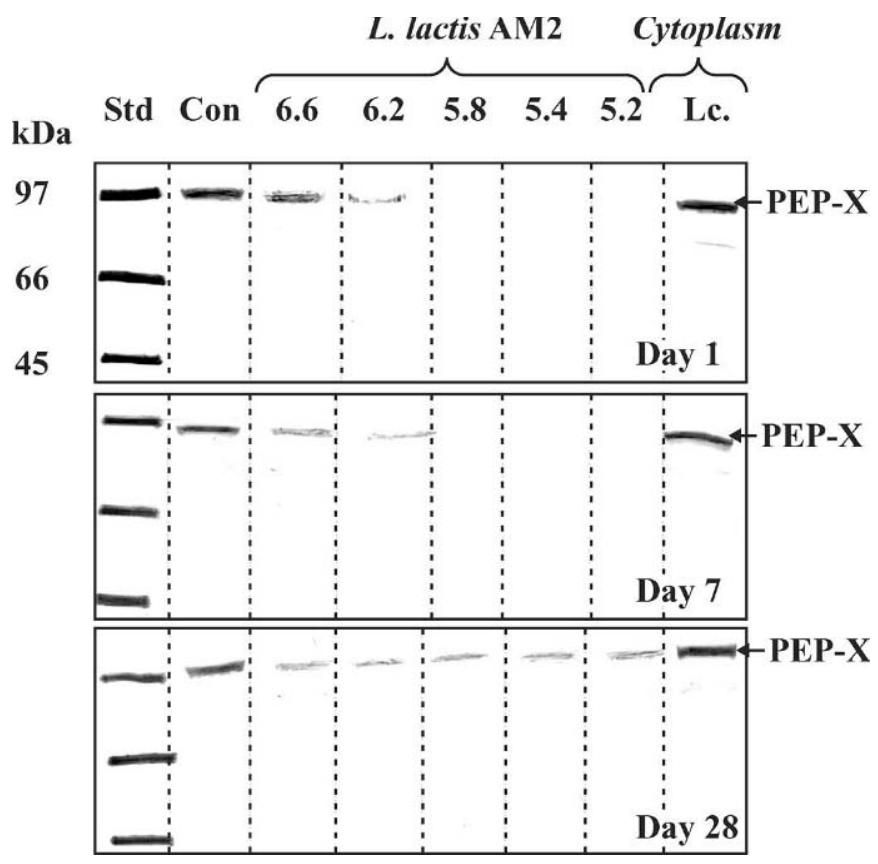

Figure 4. Immunodetection of X-prolyl-dipeptidyl-aminopeptidase (Pep-X) in cheese aqueous extracts of UF cheeses manufactured using different renneting $\mathrm{pH}$ values on $\mathrm{d} 1,7$, and 28. Each lane corresponds to a cheese made with the indicated renneting $\mathrm{pH}$. Std $=$ molecular weight standard $(\mathrm{kDa})$; Con = control (addition of cell-free extract and glucono- $\delta$-lactone to retentate); Lc. = positive control of the cytoplasm of Lactococcus lactis ssp. cremoris AM2.

is formed at $\mathrm{pH}$ 6.6. In contrast, the matrix revealed by CSLM in the cheese renneted at $\mathrm{pH} 5.2$ (Figure $5 \mathrm{~b}$ ) was very different. The white protein network was less dense and small, evenly sized, red fat globules were more evenly dispersed within the protein matrix. The black pockets representing air or aqueous phase were less numerous and smaller. The visual comparison of the 2 structures clearly showed that in cheeses renneted at $\mathrm{pH}$ 5.2, the matrix was more homogeneous in nature, which was reflected in the smooth texture observed in the final cheese.

Further investigation of the cheese structure and distribution of the starter bacteria was conducted using the LIVE/DEAD bacterial viability kit. The protein network, which is also capable of absorbing the stains, is colored brown on the micrographs, whereas fat globules appear black. As observed earlier, the protein network of the 2 cheeses is quite different at this stage. However, the distribution and organization of the bacterial cells was also very different. In cheese renneted at $\mathrm{pH} 6.6$ (Figure 5c), bacterial cells were organized as large colonies. Cells fluoresced both green and red, indicating the presence of viable cells with intact membranes and nonviable cells with compromised cell membranes. The distribution of colonies was not even throughout the network, with many fields having no colonies at all. Colonies were located in the aqueous phase, and were difficult to find and characterize due to their size and shape (not present in the same plane). In contrast, in cheese renneted at pH 5.2 (Figure 5d), cells fluoresced green indicating intact membranes, but were dispersed as single cells or small collections of cells entrapped throughout the protein matrix. In all fields observed, cells were easily visible but always dispersed. No large colonies were observed in these cheeses.

The micrographs show how similar the protein networks became after d 28 of ripening, although larger black areas of fat are still present in cheese renneted at $\mathrm{pH} 6.6$ (Figure 5e) compared with cheese renneted at $\mathrm{pH} 5.2$ (Figure 5f). In both cheeses, no cells were observed that fluoresced green, indicating that all detected cells had compromised membranes. In cheeses renneted at $\mathrm{pH} 6.6$, very few cells were observed, which was attributed to the earlier induction of lysis resulting in complete destruction of the cell wall membranes that could no longer take up the dye and fluoresce. The later induction of lysis in cheese renneted at $\mathrm{pH} 5.2$ meant that enough cells were present, albeit compromised, to take up the dyes and fluoresce.

\section{Total FAA}

The ANOVA of total FAA revealed that significant differences $(P<0.05)$ existed due to renneting $\mathrm{pH}(\mathrm{df}=$ $4, \mathrm{~F}=169.64, P \leq 0.000)$, ripening time $(\mathrm{df}=1, \mathrm{~F}=$ 1118.46, $P \leq 0.000$ ), and the interaction of renneting $\mathrm{pH}$ and ripening time $(\mathrm{df}=4, \mathrm{~F}=29.87, P \leq 0.000)$. Levels of total FAA detected on d 1 were 1.4-, 1.4-, 1.3, and 1.2-fold higher in cheeses renneted at $\mathrm{pH} 6.6$, $6.2,5.8$, and 5.4, respectively, compared with cheese renneted at pH 5.2 (Figure 6). After d 28, the level of total FAA had increased in all cheeses. However, levels detected at this stage of ripening were 1.5 times higher in cheese renneted at $\mathrm{pH} 6.6$ compared with cheese renneted at $\mathrm{pH} 5.2$ even though similar levels of lysis were detected. Hence, it can be concluded that the early induction of lysis was resulted in an increase in the level of FAA in UF cheese from the start of ripening.

\section{DISCUSSION}

The $\mathrm{pH}$ at which rennet was added to the same retentate (same initial composition, same initial inocula) was varied in this study. By renneting at various $\mathrm{pH}$ values (pH 6.6 to 5.2) a gradient of lysis of L. lactis AM2 was exhibited. On d 1, cheese renneted at $\mathrm{pH} 6.6$ showed early induction of lysis whereas cheeses renneted at lower $\mathrm{pH}$ ( $\mathrm{pH}$ 5.2) showed progressively delayed induction of lysis, as has been previously reported (Hannon 

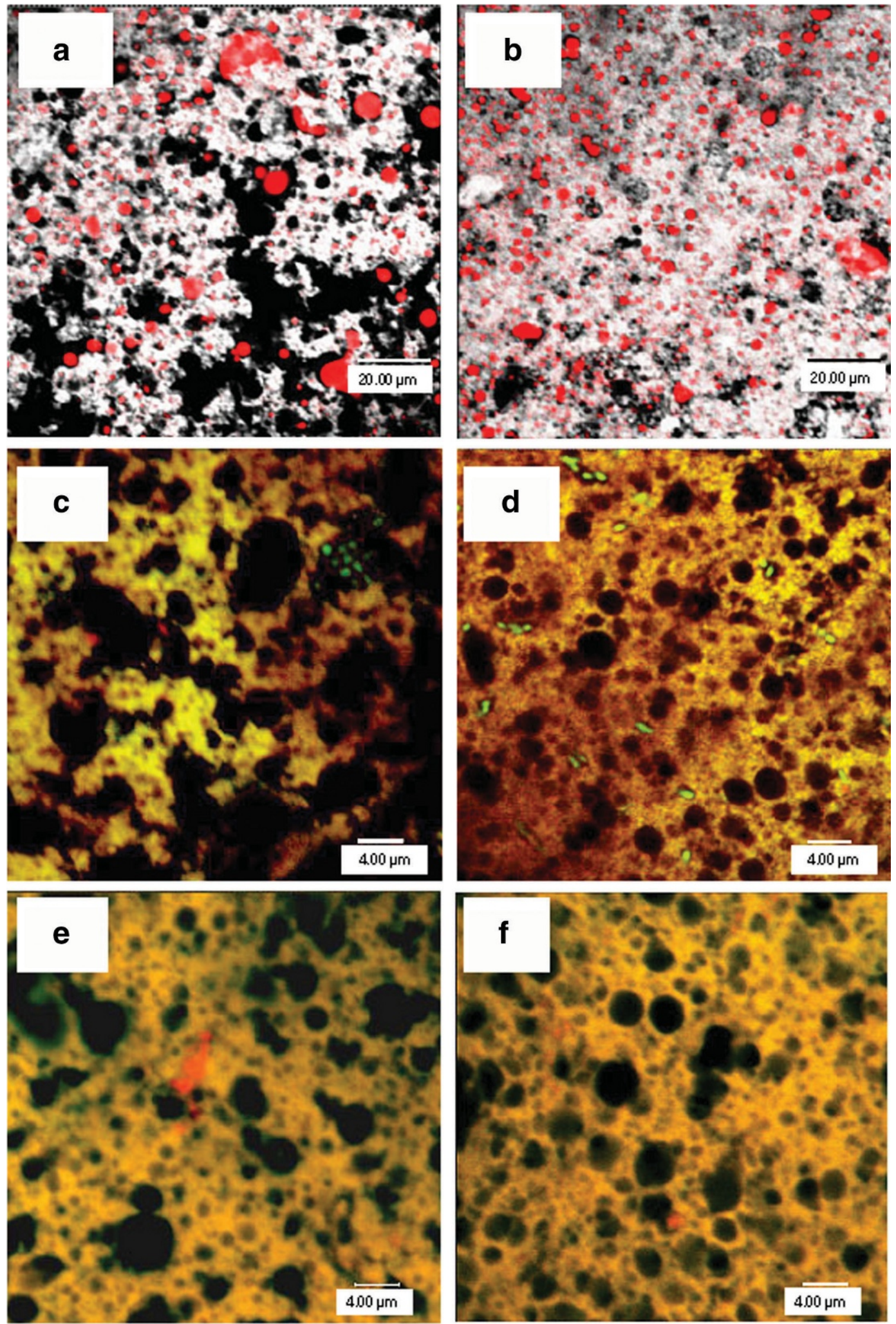

Figure 5. Confocal micrographs showing the protein and fat matrix on $\mathrm{d} 1$ in cheeses renneted at (a) $\mathrm{pH} 6.6$ and $(\mathrm{b}) \mathrm{pH} 5.2($ white $=$ proteins; red $=$ fat globules) and the organization of starter cells into colonies vs. isolated cells on $\mathrm{d} 1$ [pH $6.6(\mathrm{c})$ and $\mathrm{pH} 5.2(\mathrm{~d})]$ and $\mathrm{d} 28$ [pH $6.6(\mathrm{e})$ and pH 5.2 (f)]. Brown = proteins; spherical black holes = fat globules; green = viable cells; red = compromised nonviable cells. 


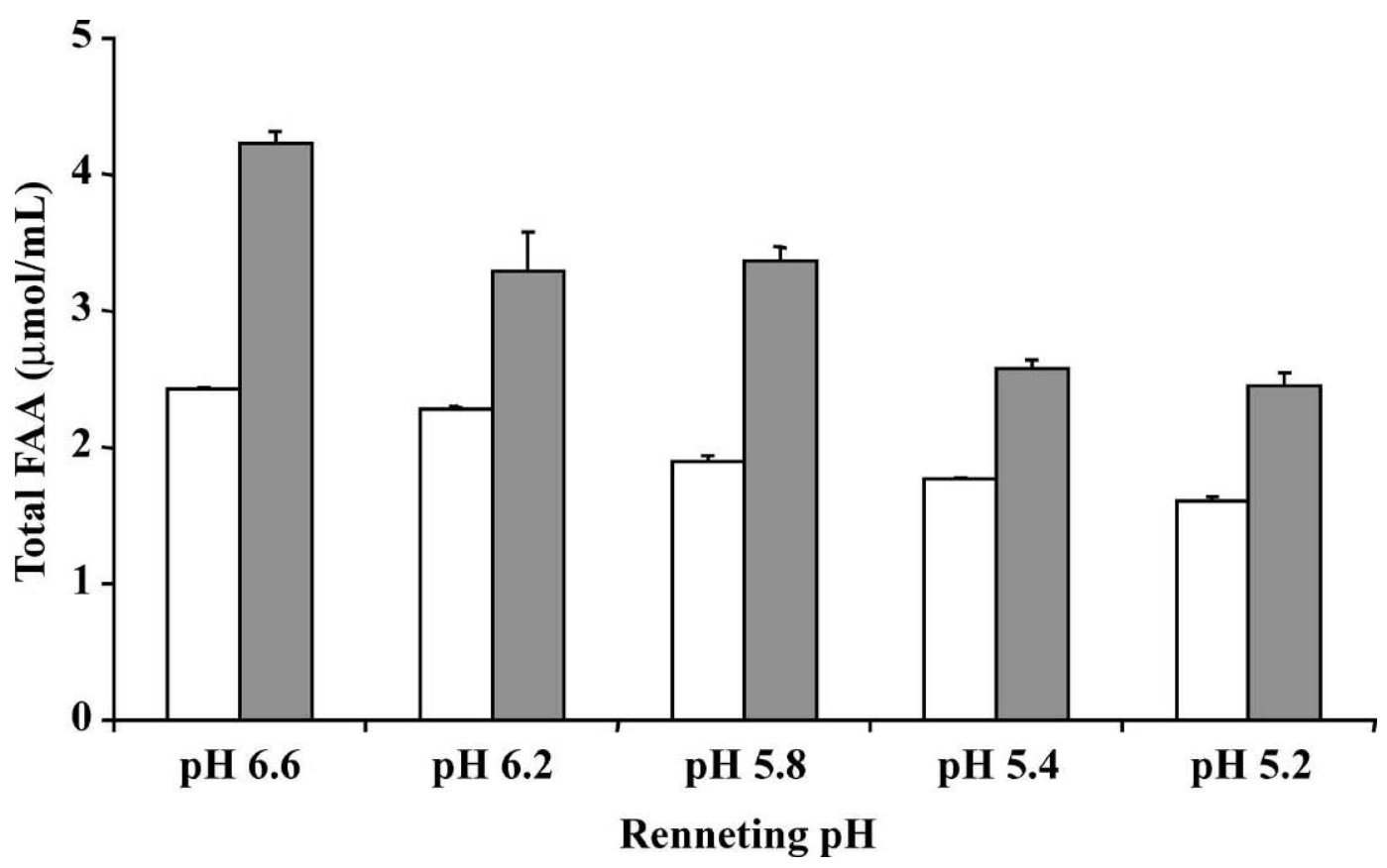

Figure 6. Levels of total free amino acids (FAA; $\mu \mathrm{mol} / \mathrm{mL}$ of cheese aqueous extract) detected in UF cheese manufactured using different renneting $\mathrm{pH}$ values at $\mathrm{d} 1(\square)$ and 28 ( $\square)$. Results are the means of 3 independent replications.

et al., 2005). To understand this gradient of lysis, we have to consider that changing the $\mathrm{pH}$ of renneting has 2 main consequences: 1 ) alterations in the cell distribution, and 2) alterations in the cheese microstructure.

As each $\mathrm{pH}$ value was attained, the retentate containing the growing bacterial cells was agitated to homogenize the rennet. This agitation also disrupted the organization of the growing cells and dispersed them throughout the retentate. Hence, cheeses renneted at higher $\mathrm{pH}$ values ( $\mathrm{pH} 6.6,6.2$, and 5.8) contained lower populations of starter cells on rennet addition. The starter cells were subsequently trapped upon formation of the gel and continued to grow in the form of colonies until cell populations had reached their final numbers. In contrast, in cheeses renneted at lower $\mathrm{pH}$ values $\mathrm{pH}$ 5.4 and 5.2), starter cell populations were already high at the time of rennet addition and, hence, no further significant growth occurred and cells did not form colonies. Agitation distributed not only the starter cells, but also growth substrates and end products $\left(\mathrm{H}^{+}\right.$and lactate). Hence, depending on the $\mathrm{pH}$ at which rennet was added, the distribution of bacterial cells as well as their microenvironments was altered in the resultant cheeses.

Alteration of the $\mathrm{pH}$ of renneting also altered the cheese microstructure. The formation of the matrix is governed largely by the physicochemical conditions of the starting material (Lawrence et al., 1983). During aggregation in traditional cheese, casein micelles ini- tially form chains that link up to form a network in which the fat globules are entrapped. As more linkages form between micelles, and fusion occurs, the structure shrinks. The aqueous phase, fat, and bacteria are squeezed out of the forming protein network and the fat globules become distorted, rupturing the membranes, and causing partial coalescence (Green et al., 1981). The $\mathrm{pH}$ has also been shown to be directly responsible for the solubility of calcium and phosphate, with levels increasing with decreasing $\mathrm{pH}$ (Le Graët and Gaucheron, 1999) in agreement with results of this study. The level of calcium binding has been shown to be crucial to the aggregative stability of the protein (Dalgleish and Parker, 1980); hence, dissociation of calcium phosphate leads to dissociation of individual caseins (Holt et al., 1986). According to Marchesseau et al. (1997) in processed cheeses, small changes in the ionic composition and strength substantially modify the protein interactions, which has significant repercussions on the final structure and quality of the protein gel. The structure of the initial matrix is of utmost importance as it determines almost completely the final structure of the cheese and consequently its texture (Green et al., 1981). Protein networks in curds made from UF milks have been reported to become progressively coarser when the concentration factor is increased (Green et al., 1981). The viscosity of retentate has been reported to decrease during acidification to $\mathrm{pH} 5.5$ after which it increases slightly at $\mathrm{pH} 5.2$ 
(Goudédranche et al., 1980). Moreover, in more viscous retentates, air bubbles are not released quickly and become incorporated into the matrix (Lelievre and Lawrence, 1988).

Addition of rennet at $\mathrm{pH} 6.6$ resulted in a coarse grainy texture, in agreement with that previously reported for concentrated retentates (Green et al., 1981). At $\mathrm{pH}$ 6.6, the level of soluble calcium was low; and strong hydrophobic interactions between native casein micelles may have formed a strong network on aggregation, stabilized by colloidal calcium-phosphate crosslinks and excluding the aqueous phase and fat globules. Partial coalescence of fat globules also resulted from this exclusion from the protein network. Green et al. (1981) have suggested that entrapped fat would disrupt the protein matrix and that increased segregation of fat from the protein network may reduce the capacity of the fat and protein phases to move in relation to each other. In contrast, cheeses renneted at low $\mathrm{pH}$ values were observed to have a very smooth, creamy texture. Acidification until pH 5.2 as well as the addition of $\mathrm{NaCl}$ led to dissociation of calcium phosphate (levels of soluble calcium were close to 5 times as high) and modification of the casein micelles, which, on addition of rennet, formed a more homogeneous matrix. Micrographs revealed that the matrix had a more even distribution of fat particles entrapped within the protein matrix. A lower number of aqueous phase or air pockets and intact fat globules with little coalescence were detected. Proteins at $\mathrm{pH} 5.2$ are more hydrated and, hence, can bind more water, which is evenly dispersed within the matrix (Gastaldi et al., 1996). At the natural $\mathrm{pH}$ of milk (6.7), both chymosin and the casein micelles have a negative charge. On lowering the $\mathrm{pH}$, the net negative charges of casein micelles and chymosin decrease, resulting in fewer possibilities for repulsion between them, favoring formation of the gel and entrapment of fat (Gastaldi et al., 1996). The different matrices obtained in this study by simply altering the renneting $\mathrm{pH}$ highlight the importance that technological properties have on cheese matrix structure.

The organization of starter cells into colonies (cheese renneted at $\mathrm{pH}$ 6.6) or small discrete units of single cells (cheese renneted at $\mathrm{pH} 5.2$ ), and the alteration of the cheese matrix microstructure appear to play a role in the induction of lysis. In cheese renneted at $\mathrm{pH} 6.6$, acid, oxidative, and nutritive stresses are likely to be involved. According to Favrot and Maubois (1996), the rapid decrease of $\mathrm{pH}$ near the colonies due to the accumulation of lactate and $\mathrm{H}^{+}$and the higher concentration of phosphoric acid would dissipate the transmembrane $\mathrm{pH}$ gradient of the cells. The more open matrix with entrapped air pockets suggested that oxidative stress may also be present in these cheeses and may contrib- ute to cell aging and cell death (van de Guchte et al., 2002). The reduction of available nutrients, especially in the center of the colonies as well as the limited diffusion in the UF matrix may be the main factors involved in triggering early induction of lysis. Nutritive stress is considered to be a main cause of induction of lysis in strains of L. lactis ssp. cremoris (Riepe et al., 1997). The presence of higher levels of stress on the bacterial cells may trigger earlier prophage induction and modify cell envelope composition (van de Guchte et al., 2002). In cheese renneted at $\mathrm{pH} 5.2$, the even distribution of bacterial cells throughout the cheese matrix is thought to reduce the acid and nutritive stresses; the more homogeneous structure is thought to reduce the oxidative stress. Although these stresses are still present in these cheeses, their reduction in levels due to alteration of the cell distribution and matrix structure may result in the delay of induction of prophage. Previous studies have shown the involvement of a prophage in the lytic behavior of L. lactis AM2 (Lepeuple et al., 1998; O'Sullivan et al., 2000). Lysis of cells due to prophage induction and concomitant release of endolysins that may act on neighboring cells in colonial growth perhaps amplifies lysis on $\mathrm{d} 1$. The even distribution of cells in the matrix and reduced diffusion in the UF matrix may impede the action of external endolysins acting on other cells and result in delayed lysis.

Despite achieving a gradient of lysis in the cheeses of this study by altering the $\mathrm{pH}$ at which rennet was added, a large difference in the level of total amino acids (indicator of proteolysis) was not observed. However, the relationship between lysis and increased proteolysis is multifactorial. Issues such as the diffusion of substrates to their enzymes within the different matrices would also affect the level of proteolysis achieved. Chymosin is an acid protease with an acid $\mathrm{pH}$ optimum, and its activity is altered by altering the $\mathrm{pH}$ (Exterkate et al., 1997). Furthermore, the decrease in the local external $\mathrm{pH}$ around colonies may affect the activities of many enzymes, including the endolysins that have a pH optimum of 6.0 to 6.9 (Sable and Lortal, 1995). However, by the end of ripening, levels of FAA were 1.5 times higher in cheese renneted at $\mathrm{pH} 6.6$ compared with that renneted at $\mathrm{pH} 5.2$, indicating that an earlier induction of lysis resulted in an increased rate of proteolysis.

\section{CONCLUSIONS}

The results of this study show that by altering the $\mathrm{pH}$ of renneting ( $\mathrm{pH} 6.6$ to 5.2) during the manufacture of UF cheese, a gradient of lysis of L. lactis AM2 is exhibited at the start of ripening. The influence of the cheese microstructure and the distribution of bacterial 
cells (cells organized in colonies vs. evenly distributed) within the different matrices was shown for the first time to play a role in the onset of lysis of L. lactis AM2. Addition of rennet before acidification ( $\mathrm{pH}$ 6.6) resulted in the detection of lysis from the start of ripening, whereas addition of rennet after acidification $(\mathrm{pH} 5.2)$ resulted in the delayed lysis. Similar levels of lysis were detected by the end of ripening irrespective of the $\mathrm{pH}$ of renneting. However, the earlier induction of lysis was shown to increase the level of FAA in UF cheese, which may enhance the flavor profiles of the final cheeses.

\section{ACKNOWLEDGMENTS}

The authors would like to thank M.-P. Chapot-Chartier for donating antibodies, J.-Y. Gassi for ultrafiltration, J. Fauquant for microfiltration, E. Beaucher for compositional analysis, and R. Primault (Microscopy department, University of Rennes, France) for technical assistance in confocal scanning laser microscopy. The authors also thank J. L. Maubois and G. Brulé for reviewing the manuscript and for fruitful discussion.

\section{REFERENCES}

Baer, A., I. Riba, J. Meyer, and U. Butikofer. 1996. Microplate assay of free amino acids in Swiss cheeses. Lebensm. Wiss. Technol. 29:58-62.

Bastian, E. D., K. G. Hansen, and R. J. Brown. 1991. Activation of plasmin with urokinase in ultrafiltered milk for cheese manufacture. J. Dairy Sci. 74:3669-3676.

Chapot-Chartier, M. P., C. Deniel, M. Rousseau, L. Vassal, and J. C. Gripon. 1994. Autolysis of two strains of Lactococcus lactis during cheese ripening. Int. Dairy J. 4:251-269.

Cogan, T. M., M. O’Dowd, and D. Mellerick. 1981. Effects of $\mathrm{pH}$ and sugar on acetoin production from citrate by Leuconostoc lactis. Appl. Environ. Microbiol. 41:1-8.

Creamer, L. K., M. Iyer, and J. Lelièvre. 1987. Effect of various levels of rennet addition on characteristics of Cheddar cheese made from ultrafiltered milk. N.Z. J. Dairy Sci. Technol. 22:205-214.

Dalgleish, D. G., and T. G. Parker. 1980. Binding of calcium ions to bovine $\alpha$ S1-casein and precipitability of the protein calcium-ion complex. J. Dairy Res. 47:113-122.

de Koning, P. J., R. de Boer, P. Both, and P. F. C. Nooy. 1981. Comparison of proteolysis in a low-fat semi-hard type of cheese manufactured by standard and ultrafiltration techniques. Neth. Milk Dairy J. 35:35-46.

Deutsch, S.-M., T. Ferain, J. Delcour, and S. Lortal. 2002. Lysis of lysogenic strains of Lactobacillus helveticus in Swiss cheeses and first evidence of concomitant Streptococcus thermophilus lysis. Int. Dairy J. 12:591-600.

Exterkate, F. A., F. M. Lagerwerf, J. Haverkamp, and S. van Schalkwijk. 1997. The selectivity of chymosin action on $\alpha$ s $1-$ and $\beta$ caseins in solution is modulated in cheese. Int. Dairy J. 7:47-54.

Favrot, C., and J. L. Maubois. 1996. Growth of Lactococcus lactis in milk and rennet curd: Influence of the level of inoculation. Lait 76:193-208.

Gardiner, G. E., E. O'Sullivan, J. Kelly, M. A. E. Auty, G. F. Fitzgerald, J. K. Collins, R. P. Ross, and C. Stanton. 2000. Comparative survival of human derived Lactobacillus paracasei and L. salivarius strains during heat treatment and spray drying. Appl. Environ. Microbiol. 66:2605-2616.
Gastaldi, E., A. Lagaude, and B. Tarodo de la Fuente. 1996. Micellar transition state in casein between $\mathrm{pH} 5.5$ and 5.0. J. Food Sci. 61:59-68.

Goudédranche, H., P. Ducruet, J.-C. Vachot, R. Pannetier, and J. L. Maubois. 1986. Utilisation du lysozyme en tant qu'agent régulateur de l'affinage en fromagerie MMV. Lait 66:189-206.

Goudédranche, H., J. L. Maubois, P. Ducruet, and M. Mahaut. 1980. Utilisation of the new mineral UF membrane for making semihard cheeses. Desalination 35:243-258.

Goudédranche, H., J. L. Maubois, P. Ducruet, and M. Mahaut. 1981. Utilisation de nouvelles membranes minérales d'ultrafiltration pour la fabrication de fromages du type Saint-Paulin. Technol. Lait. 950:7-12.

Green, M. L., A. Turvey, and D. G. Hobbs. 1981. Development of structure and texture in Cheddar cheese. J. Dairy Res. 48:343355.

Hannon, J. A., S.-M. Deutsch, M.-N. Madec, J.-Y. Gassi, M.-P. ChapotChartier, and S. Lortal. 2006. Lysis of starters in UF cheeses: Behaviour of mesophilic lactococci and thermophilic lactobacilli. Int. Dairy J. 16:324-334.

Hannon, J. A., M. G. Wilkinson, C. M. Delahunty, J. M. Wallace, P. A. Morrissey, and T. P. Beresford. 2003. Use of autolytic starter systems to accelerate the ripening of Cheddar cheese. Int. Dairy J. 13:313-323.

Holt, C., D. T. Davies, and A. J. R. Law. 1986. Effects of colloidal calcium phosphate content and free calcium ion concentration in the milk serum on the dissociation of bovine casein micelles. J. Dairy Res. 53:557-572.

IDF. 1982. Cheese and processed cheese-determination of total solids content. IDF Standard 4a. Int. Dairy Fed., Brussels, Belgium.

Klein, N., and S. Lortal. 1999. Attenuated starters: An efficient means to influence cheese ripening-A review. Int. Dairy J. 9:751-762.

Lawrence, R. C., J. Gilles, and L. K. Creamer. 1983. The relationship between cheese texture and flavour. N.Z. J. Dairy Sci. Technol. 18:175-190.

Le Graët, Y., and F. Gaucheron. 1999. pH-induced solubilisation of minerals from casein micelles: Influence of casein concentration and ionic strength. J. Dairy Res. 66:215-224.

Lelievre, J., and R. C. Lawrence. 1988. Manufacture of cheese from milk concentrated by ultrafiltration. J. Dairy Res. 55:465-478.

Lepeuple, A. S., L. Vassal, B. Cesselin, A. Delacroix-Buchet, J. C. Gripon, and M. P. Chapot-Chartier. 1998. Involvement of a prophage in the lysis of Lactococcus lactis subsp. cremoris AM2 during cheese ripening. Int. Dairy J. 8:667-674.

Lortal, S., and M. P. Chapot-Chartier. 2005. Role, mechanisms and control of lactic acid bacteria lysis in cheese. Int. Dairy J. 15:857-871.

Marchesseau, S., E. Gastaldi, A. Lagaude, and J.-L. Cuq. 1997. Influence of $\mathrm{pH}$ on protein interactions and microstructure of process cheese. J. Dairy Sci. 80:1483-1489.

Maubois, J.-L., and G. Mocquot. 1971. Préparation de fromage à partir de pré-fromage liquide obtenu par ultrafiltration du lait. Lait 508:495-533.

Maubois, J.-L., G. Mocquot, and L. Vassal. 1969. A method for processing milk and dairy products, French Patent, FR 2052121.

Mistry, V. V., and J.-L. Maubois. 2004. Application of membrane separation technology to cheese production. Pages 261-285 in Cheese: Chemistry, Physics and Microbiology, Volume 1, General Aspects. 3rd ed. P. F. Fox, P. L. H. McSweeney, T. M. Cogan, and T. P. Guinee, ed. Elsevier, London, UK.

O'Sullivan, D., R. P. Ross, G. F. Fitzgerald, and A. Coffey. 2000. Investigation of the relationship between lysogeny and lysis of Lactococcus lactis in cheese using prophage-targeted PCR. Appl. Environ. Microbiol. 66:2192-2198.

Pedersen, P. J., and N. Ottosen. 1992. Manufacture of fresh cheese by ultrafiltration. Pages 67-76 in New applications of membrane process. Special issue 9201, Int. Dairy Fed., Brussels, Belgium.

Qvist, K. B., D. Thomsen, and E. Hoier. 1987. Effect of ultrafiltered milk and the use of different starters on the manufacture, fermentation and ripening of Havarti cheese. J. Dairy Res. 54:437-446.

Riepe, H. R., C. J. Pillidge, P. K. Gopal, and L. L. McKay. 1997. Characterisation of the highly autolytic Lactococcus lactis subsp. 
cremoris strains $\mathrm{CO}$ and 2250. Appl. Environ. Microbiol. 63:3757-3763.

Sable, S., and S. Lortal. 1995. The lysins of bacteriophages infecting lactic acid bacteria. Appl. Microbiol. Biotechnol. 43:1-6.

Saboya, V. L., H. Goudédranche, J.-L. Maubois, A. L. S. Lerayer, and S. Lortal. 2001. Impact of broken cells of lactococci or propionibacteria on the ripening of Saint-Paulin UF-cheeses: Extent of proteolysis and GC-MS profiles. Lait 81:699-713.

Saboya, V. L., S. Lortal, A. L. S. Lerayer, and J.-L. Maubois. 2002. Absence of lactococci lysis in ultrafiltered cheeses. Proc 26th Int. Dairy Fed., Paris, France. Int. Dairy Fed., Brussels, Belgium.

Spangler, P. L., M. El Soda, M. E. Johnson, N. F. Olson, C. H. Amundson, and C. G. Hill, Jr. 1989. Accelerated ripening of Gouda cheese made from ultrafiltered milk using a liposome entrapped enzyme and freeze shocked lactobacilli. Milchwissenschaft 44:199-203.

Terzaghi, B. E., and W. E. Sandine. 1975. Improved medium for lactic streptococci and their bacteriophages. Appl. Microbiol. 29.807813.
Towbin, H., T. Staehelin, and J. Gordon. 1979. Electrophoretic transfer of proteins from polyacrylamide gels to nitrocellulose sheets: Procedure and some applications. Proc. Natl. Acad. Sci. USA $76: 4350-4354$.

Valence, F., and S. Lortal. 1995. Zymogram and preliminary characterisation of Lactobacillus helveticus autolysins. Appl. Environ. Microbiol. 61:3391-3399.

Valence, F., R. Richoux, A. Thierry, A. Palva, and S. Lortal. 1998. Autolysis of Lactobacillus helveticus and Propionibacterium freundenreichii in Swiss cheese: First evidence by using speciesspecific markers. J. Dairy Res. 65:609-620.

van de Guchte, M., P. Serror, C. Chervaux, T. Smokvina, S. D. Ehrlich, and E. Maguin. 2002. Stress response in lactic acid bacteria. Antonie Leeuwenhoek Int. J. Gen. Med. 82:187-216.

Visser, S. 1981. Proteolytic enzymes and their action on milk proteins: A review. Neth. Milk Dairy J. 35:65-88.

Wilkinson, M. G., T. P. Guinee, D. M. O'Callaghan, and P. F. Fox. 1994. Autolysis and proteolysis in different strains of starter bacteria during Cheddar cheese ripening. J. Dairy Res. 61:249-262. 